\title{
Roads to nowhere: footnotes on a classic
}

\section{Maxwell Gordon Lay: The harnessing of power: how nineteenth-century transport innovators transformed the way the world operates. Newcastle: Cambridge Scholars Publishing, 2018, 374 pp, $£ 64.99$ HB}

\section{Silke Zimmer-Merkle ${ }^{1}$}

Published online: 27 July 2020

(c) The Author(s) 2020

When professors retire, they have accumulated an immense amount of precious knowledge during their academic life. Quite a few use this period of relative calm to finally put what they had always wanted to say between two book covers. In many cases, this is a generous gift to humanity. More often than not, the fruit of such labor is a welcome synthesis of the author's life's work. Some use it to give an academic overview of their work, while others try out new ideas, departing from the beaten track to test experimental approaches guided by a lifetime's experience. And some just finish what they had once started, using forgotten notes found while cleaning out their desk drawers.

Maxwell Gordon Lay is a renowned road and traffic engineer based in Australia. $\mathrm{He}$ is an author of many specialist articles on infrastructure and roadmaking and the Handbook of Road Technology as well as a publication in road history from the 1990s. Now in his eighties, he has published another historical book. Working on the history of technology, it is refreshing to find good reads with internalist views, particularly if they are up-to-date, with a socio-technical perspective. The back cover of The Harnessing of Power promises no less than to examine "how the nineteenth century's transport legacy of bicycles, trains, ocean-going steamers, trucks, trams, buses and cars arose, creating numerous new technologies and markets." A concise history of the nineteenth-century mobility revolution in (not even) four hundred pages.

"The fact that I am an engineer clearly colours my views and influences my interpretations and I suspect that historians reading this work wish that I had been better schooled in their methods of historical research. On the other hand, one of the drivers of my interest in transport history has been the way in which some otherwise

Silke Zimmer-Merkle

silke.zimmer-merkle@kit.edu

1 History Department - Institute of Technology Futures, Karlsruhe Institute of Technology (KIT), Karlsruhe, Germany 
very capable historians have misunderstood, often grossly the engineering aspect of the issues they were describing." (323).

Occasionally, authors succeed in identifying the strengths and weaknesses of their own book themselves, and this is the case here. Let me explain. When I agreed to review Lay's new book, I was very much looking forward to it, given that his Ways of the World: A History of the World's Roads and of the Vehicles that Used Them is still a classic. Although most historians today are no friends of histories of inventions and master narratives about inventors, the present book intrigued me, as with his first book in transport history Lay had presented a very modern and progressive perspective that some of his colleagues in history of transport and technology were still lacking at the time. Additionally, the relevance of the nineteenth century in the history of mobility is widely recognized, but still under-investigated. When I finally opened the book and checked the table of contents, list of references, index, and so on, I started to wonder. Where were the inventors announced in the title? And where was the "power"? The table of contents left me puzzled. The book consists of nineteen parts, which are relatively short, and the chapters in these parts are even shorter. Some parts only consist of one short chapter (e.g., part two has 7 pages, part six 5 pages). Translating "parts" into "chapters" and "chapters" into "sub-chapters" might make more sense. Most parts have telling names like "Roads in the 18th and Early nineteenth Centuries" (part 3), "The First Commercial Railway" (part 10), or "The Steam-powered Road Carriage" (part 13). Corresponding sub-chapters are named "British roads" (chapter 3a), "Servicing Liverpool and Manchester" (chapter 10a) and "The Mid-life Fiasco" (chapter 13a). But where are the inventors? The only people that could be identified from the table of contents were Karl Benz and Gottlieb Daimler (chapters 14c and 16a) along with the ten-page-long part 18 on "People", containing the chapters "Population Effects" and "Change-makers". Perhaps, the inventors are hidden inside the chapters? Power seemed - to some extent at least- to appear: There are parts on "People Power" (part 2), "Steam: A New Source of Useful Power" (part 8), accompanied by two more parts on steam power (parts 13 and 14), and "Portable Power" (part 15) on "Petroleum-based Fuels" (chapter 15a) and "Invisible Power" (chapter 15b) referring to electrical drives.

With this strange first impression, I was not sure what to expect anymore. Just another transport history? Old wine in the same old skins? The combined "Preface and Introduction" indeed gave an answer: "The question that increasingly came to my mind was how that creative nineteenth century legacy had arisen? How did transport reach the transformative stage that it did at the end of the nineteenth centuryso many changes, so many new technologies, so many new markets?" (xiii) This research question, while not particularly new or fancy, is nevertheless legitimate.

Lay announces a focus on British history: "How Britain lost, or even threw away its leadership, is a story that I explore within the wider thrust of this book." (xiv) What role the "Harnessing of Power" would play in this context is not mentioned in the two-page preface-introduction. Instead, he explains that he had "tried to do whatever possible to highlight and pay homage to the many individual inventors and innovators and entrepreneurs who caused the dramatic transport changes that occurred during the nineteenth century." (xiv) Neither pseudo historico-political programs - the "thrown away" British leadership—nor "homages" are what 
historians are necessarily keen on reading. Nevertheless, as biographical approaches can be insightful, I thought it worthwhile persisting.

To cut a long story short... The Harnessing of Power falls far behind Lay's earlier Ways of the World. It is not only his old-school approach to transport history that poses a problem, the book is also methodologically outdated, missing out on modern mobility study approaches, as explored by John Urry and other scholars in the field (e.g., Urry 2007). Although Lay states modestly: "I write as an engineer specializing in transport and certainly not as an historian," (xiii) the expectation has become a different one since the 1990s. Time has passed, research has been done, but it is not to be found in Lay's book. A look into the references reveals that from around 225 pieces of the literature, only 38 are from the year 2000 or later-11 of them are from Lay himself, the others mainly general history, few transport-related; and not more than 9 are from 2010 or later.

In this book, Lay retells in a new order what we already read in Ways of the World-but his earlier book was composed in an appealing and coherent way. The Harnessing of Power misses the mark; the presentation of the facts appears disconnected, references are scarce, the narration seems anecdotic. For example: You probably knew that macadam pavement has nothing to do with macadamia nuts. But did you know that macadam is named after one of its inventors, John Loudon McAdam, a Scottish road engineer? (53) Lay already pointed this out in Ways of the World. Intending to pay homage to inventors would lead one to expect a more detailed account, but the short chapter on the road engineers Thomas Telford and John McAdam does not give significantly more information about them than we could already read in the old book. The history of transport appears similarly fragmentary. Already in the 1990s, Lay's take on the topic had been a short and sketchy one. Although The Harnessing of Power promises to tell just that story-and Lay dedicates half of the book to the history of vehicles-his presentation is not even close to state-of-the-art, and far from exhaustive.

Thus, whoever is interested in the history of roads and road engineering is advised to read Lay's 1992 book which is (although research has continued, offering new insights) still a classic and worth reading; it has aged well. Anyone interested in the history of motor vehicles should instead look at Gijs Mom's gigantic and genial Atlantic Automobilism (Mom 2015) that will soon be followed by a global history of the car. If you are really into the history of roads and Ways of the World was insufficient for you, The Harnessing of Power might offer a minor addendum of anecdotal notes and footnotes to his earlier work (Lay 1992). Anyway, it invites the reader to revisit this classic book.

\section{Acknowledgements Open Access funding provided by Projekt DEAL.}

Open Access This article is licensed under a Creative Commons Attribution 4.0 International License, which permits use, sharing, adaptation, distribution and reproduction in any medium or format, as long as you give appropriate credit to the original author(s) and the source, provide a link to the Creative Commons licence, and indicate if changes were made. The images or other third party material in this article are included in the article's Creative Commons licence, unless indicated otherwise in a credit line to the material. If material is not included in the article's Creative Commons licence and your intended use is 
not permitted by statutory regulation or exceeds the permitted use, you will need to obtain permission directly from the copyright holder. To view a copy of this licence, visit http://creativecommons.org/licen ses/by/4.0/.

\section{References}

Lay, Maxwell Gordon. 1992. Ways of the World. A History of the World's Roads and of the Vehicles That Used Them. New Brunswick, New Jersey: Rutgers University Press.

Mom, Gijs. 2015. Atlantic Automobilism: Emergence and persistence of the car 1895-1940. New York, Oxford: Berghahn.

Urry, John. 2007. Mobilities. Cambridge: Polity.

Publisher's Note Springer Nature remains neutral with regard to jurisdictional claims in published maps and institutional affiliations. 